\title{
SIMPLIFIED ESTIMATION OF CALCIUM IN BIOLOGICAL MATERIALS BY FLAME PHOTOMETRY
}

\author{
BY \\ J. G. LLAURADO \\ From the Postgraduate Medical School, London
}

(RECEIVED FOR PUBLICATION SEPTEMBER 3, 1953)

Flame photometry has introduced rapidity, accuracy, and simplicity into the estimation of sodium and potassium in biological materials. When it is desired to prepare for the estimation by flame photometry of $\mathrm{Ca}^{++}$in serum containing $\mathrm{Na}^{+}$ and $\mathrm{K}^{+}$merely by diluting with distilled water, it must be kept in mind that for every $10 \mathrm{mg}$./ $100 \mathrm{ml}$. of $\mathrm{Ca}^{++}$there is $325 \mathrm{mg} . / 100 \mathrm{ml}$. of $\mathrm{Na}^{+}$. Furthermore, the sodium spectrum lines are very near to, and more intense than, those of $\mathrm{Ca}^{++}$ so that $\mathrm{Ca}^{++}$values obtained in this way are greater than actual values.

Following the wide use of flame photometry since 1945 (Barnes, Richardson, Berry, and Hood, 1945) many attempts have been made to estimate calcium; unsuccessful data remain unpublished, and hitherto reported methods are inaccurate or tedious.

In one of the earliest reports in this field Belke and Dierkesmann (1948) attempted the estimation using a flame photometer equipped with acetylene gas and a green filter reputedly not absorbing completely $\mathrm{Na}^{+}$and $\mathrm{K}+$ lights. Attempts were made to allow for $\mathrm{Na}^{+}$and $\mathrm{K}^{+}$interference by the addition of comparable amounts of these elements to the standard $\mathrm{Ca}^{++}$solutions. The accuracy of this procedure is impaired by relative variability of $\mathrm{Na}^{+}$and $\mathrm{K}^{+}$levels in biological fluids and also by the fact that $\mathrm{Ca}^{++}$per se is not measured.

Herrmann (1952) has described a method for the estimation of calcium, in which the main features are the recording of the green line in the $\mathrm{Ca}^{++}$spectrum at $558 \mathrm{~m} \mu$, the use of acetylene gas for combustion, and a simple serum dilution of 1 in 5. Neither normal values for $\mathrm{Ca}^{++}$in serum nor objective data are reported, but this method has been used by Bohnstedt, Herrmann, Baumann, and Füller (1953) to estimate the $\mathrm{K}^{+} / \mathrm{Ca}^{++}$ serum ratio in normal subjects and eczematous patients. Isolated values for $\mathrm{K}^{+}$and $\mathrm{Ca}^{++}$are not given in this paper, and a remark is made that " bei unserer Methode die $\mathrm{K} / \mathrm{Ca}$-Quotienten stets relativ niedrige Werte ergaben." The value for $\mathrm{Ca}^{++}$can, however, be determined theoretic- iv ally from their data: for normal people the ratio is given as 1.54 , and, if the accepted normal $\mathrm{K}+\overrightarrow{0}$ serum value of $20 \mathrm{mg}$./100 is considered, the "normal" for $\mathrm{Ca}^{++}$serum by this method is $13 \mathrm{mg} . / 100$. This value is high and agrees with $\vec{Z}$ values found by us when $\mathrm{Ca}++$ was estimated merely by dilution of serum.

It has been realized for some time that this problem could be solved by precipitating $\mathrm{Ca}^{++}$, thus removing interfering cations and carrying out the estimations on the redissolved and suitably diluted $\mathrm{Ca}^{++}$sample.

The manufacturers of the Beckman spectro- $\frac{\otimes}{\infty}$ photometer with flame attachment recognize (Application Data, DU-9-B) the necessity of pre- $\stackrel{0}{\vec{O}}$ cipitating $\mathrm{Ca}^{+}+$in $\mathrm{Na}^{+}$and $\mathrm{K}^{+}$mixtures in spite of all the advantages of this apparatus. Precipitated calcium oxalate is washed, centrifuged, and taken up in perchloric acid and isopropylalcohol. 웅 Explanations for the use of these two substances: are not given. Acetylene gas is also used in this method.

While our investigations were being carried out Schlütz (1953) described a method based on the same principle of precipitation as calcium oxalate. No advantage is really gained with this method over the usual chemical methods, since three centrifugations and two washings are required.o Furthermore, no details of the filter used are given $N$ and no objective data showing sensitivity and accuracy are reported. Acetylene gas was also usedo in this case.

Since the start of these investigations, the aim $\frac{0}{\varnothing}$ has been to establish a method to estimate the true amount of $\mathrm{Ca}^{++}$in biological materials under 0 the following conditions: (1) without $\mathrm{Na}^{+}$and $\mathrm{K}^{+}$interference; (2) saving time on the ordinary chemical methods, especially the two or more washings, re-centrifugations, and tedious titra- $\frac{0}{0}$ tion; (3) adapted to a simple flame photometer, using coal-gas and compressed air instead ofo acetylene gas and additional oxygen. 
An Evans " electroselenium" Ltd. flame photometer supplied with coal-gas and compressed air from a cylinder was used. Air pressure was adjusted at $10 \mathrm{lb}$. $/ \mathrm{sq}$. in. $\left(0.7 \mathrm{~kg} . / \mathrm{cm}^{2}\right)$. The gas was regulated to produce 10 small cone-shaped flames at the top of the burner. Working with this empirical procedure, flame conditions usually change each time the burner is lit. This is obviated by interpolating with the unknown samples immediately higher and lower standards. Nevertheless, an absolute relationship, as shown below, between deviations in galvanometer scale-readings and concentrations of $\mathrm{Ca}^{++}$exists. An interference filter with a peak at $620 \mathrm{~m} \mu$ and additional special didymium glass to cut out interference by $\mathrm{Na}^{+}$was used.

With these conditions a whole deflexion of the galvanometer scale is reached with 30 p.p.m. of $\mathrm{Ca}^{++}$when the potentiometer is adjusted to 1 . Sometimes, however, due to variations in the supply or quality of gas, a complete deflexion is not reached with 30 p.p.m. For this reason, a 40 p.p.m. $\mathrm{Ca}^{+}+$solution is used as the strongest, and the potentiometer is adjusted between 1 and 2 until the whole deflexion is recorded in the scale of the galvanometer.

\section{Preliminary Experiments}

The first objective was to establish a linear relationship between deviations of the galvanometer scalereading and the concentrations of $\mathrm{Ca}++$ in a mixture containing no other cations: this simple relationship in a range from 0 to $\mathbf{4 0}$ p.p.m. is obvious from Fig. 1. Therefore, estimations of solutions containing only $\mathrm{Ca}++$ do not represent any problem with this type of flame photometer.

The second objective was to measure the $\mathrm{Ca}++$ content in samples of normal serum by simple dilution with distilled water. Values of about $13 \mathrm{mg}$./ $100 \mathrm{ml}$. were obtained by this procedure.

Finally it was necessary to determine the efficiency of the $\mathrm{Ca}++$ filter in cutting out light due to $\mathrm{Na}+$ and $\mathrm{K}^{+}$. Standard samples of $\mathrm{Na}^{+}$and $\mathrm{K}^{+}$were sprayed in the flame photometer. A Na+ content of 8 p.p.m. $(0.8 \mathrm{mg} . / 100 \mathrm{ml}$. $)$ and a $\mathrm{K}+$ content of 7.5 p.p.m. $(0.75 \mathrm{mg} . / 100 \mathrm{ml}$.) do not produce any deviation when the filter for $\mathrm{Ca}++$ is tested. As, on the other hand, other trials showed (see below) that the $\mathrm{Na}+$ contained as impurity or residuum in the precipitated samples of $\mathrm{Ca}++$ does not exceed this amount, this experiment assured that below that range all light due to $\mathrm{Na}+$ and $\mathrm{K}+$ was cut off.

\section{Preparations of Standards}

Calcium chloride prepared in the following way was used: Anala $\mathrm{CaCO}_{3}$ is put in the oven overnight at $40^{\circ}$ C. to dry it. Next day $12.5 \mathrm{~g}$., which represents exactly $5,000 \mathrm{mg}$. of $\mathrm{Ca}$, is weighed out. This is suspended with a small amount of distilled water in a volumetric flask and $\mathrm{Na}$-free $\mathrm{N}-\mathrm{HCl}$ is added (about $250 \mathrm{ml}$.) until it is completely dissolved. This is made

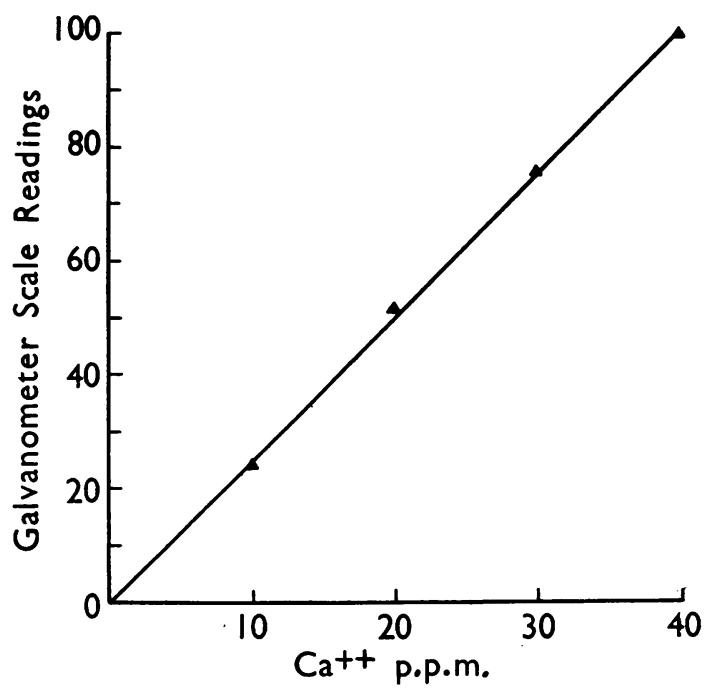

FIG. 1.-Linear relationship between galvanometer scale-readings and other cation-free $\mathrm{Ca}^{++}$solutions.

up to 1.1 with distilled water. This solution is called the stock solution, and when kept in the refrigerator can be used indefinitely. From the stock solution the following standard solutions are prepared:

\begin{tabular}{|c|c|c|}
\hline Solution & $\begin{array}{l}\text { Stork Solution (ml.) } \\
\text { Made up to } 1,000 \mathrm{ml} \text {. } \\
\mathrm{H}_{2} \mathrm{O}\end{array}$ & $\stackrel{\text { Cantent in p.p.m. }}{\text { Con.+ }}$ \\
\hline $\begin{array}{l}\mathbf{A} \\
\mathbf{B} \\
\mathbf{C} \\
\mathbf{D}\end{array}$ & $\begin{array}{l}2 \\
4 \\
6 \\
8\end{array}$ & $\begin{array}{l}10 \\
20 \\
30 \\
40\end{array}$ \\
\hline
\end{tabular}

Solutions used for recovery were either the same standard solutions or solutions prepared from stock solution.

\section{Precipitation of $\mathbf{C a}^{++}$Samples}

Samples containing $5 \mathrm{mg}$., $7.5 \mathrm{mg}$., $10 \mathrm{mg}$., $12.5 \mathrm{mg}$., and $15 \mathrm{mg} . / 100 \mathrm{ml}$. of $\mathrm{Ca}++$ were used. Two lots were made : (1) containing only $\mathrm{Ca}++$, and (2) $\mathrm{Ca}++$ dissolved in a solution of $\mathrm{NaCl}$, containing $305 \mathrm{mg}$./ $100 \mathrm{ml}$. of $\mathrm{Na}^{+}$, a concentration similar to that of serum.

Two millilitres of each sample was taken, precipitated with ammonium oxalate, and allowed to stand for 30 minutes. Four millilitres distilled water was then added and the solution was centrifuged. The supernatant fluid was discarded, the precipitate dried and redissolved with $10 \mathrm{ml} .0 .2 \mathrm{~N}-\mathrm{HCl}$.

Samples of the solutions containing only $\mathrm{Ca}++$ were also estimated directly, i.e., without any manipulation. As a rule, values found after precipitation were lower than those found by direct estimation. Results are shown in Table I. From this experiment 
TABLE I

RESULTS OF PRECIPITATING CALCIUM SAMPLES

\begin{tabular}{|c|c|c|c|c|c|c|c|c|c|}
\hline \multirow{3}{*}{$\begin{array}{l}\text { Theoretical } \\
\text { Values } \\
(\mathrm{mg} . / 100 \mathrm{ml} .)\end{array}$} & \multirow{3}{*}{$\begin{array}{c}\text { Samples } \\
\text { Estimated } \\
\text { Directly } \\
\text { by Flame } \\
\text { Photometer }\end{array}$} & \multicolumn{3}{|c|}{ Samples Precipitated } & \multicolumn{5}{|c|}{ Samples Precipitated Containing $305 \mathrm{mg} . / 100 \mathrm{ml} . \mathrm{Na}^{+}$} \\
\hline & & \multirow{2}{*}{$\underset{\text { Content }}{\mathrm{Ca}^{++}}$} & \multirow{2}{*}{$\mid \begin{array}{c}\mathrm{Na}^{+} \text {Content } \\
\text { (mg./100 ml.) } \\
\text { as Impurity }\end{array}$} & \multirow{2}{*}{$\mid \begin{array}{c}\mathrm{Ca}^{++} \text {Content } \\
\text { of Decanted } \\
\text { Water }\end{array}$} & \multirow{2}{*}{$\mathrm{Ca}^{++}$} & \multirow{2}{*}{$\mathrm{Na}^{+}$} & \multicolumn{2}{|c|}{ Duplicate } & \multirow{2}{*}{$\begin{array}{l}\text { Mean } \\
\mathrm{Ca}^{++}\end{array}$} \\
\hline & & & & & & & $\mathrm{Ca}^{++}$ & $\mathbf{N a}^{+}$ & \\
\hline $\begin{array}{l}5 \\
7 \cdot 5 \\
10 \cdot 0 \\
12 \cdot 5 \\
15 \cdot 0\end{array}$ & $\begin{array}{r}4 \cdot 9 \\
7 \cdot 5 \\
10 \cdot 0 \\
12 \cdot 5 \\
15 \cdot 0\end{array}$ & $\begin{array}{c}4 \cdot 6 \\
5.8 \\
9 \cdot 1 \\
11.06 \\
12 \cdot 5\end{array}$ & $\begin{array}{l}0.5 \\
0.5 \\
0.49 \\
0.62 \\
0.42\end{array}$ & $\begin{array}{l}\mathbf{0} \\
\mathbf{0} \\
0 \\
0 \\
0\end{array}$ & $\begin{array}{r}5 \cdot 6 \\
7 \cdot 4 \\
10 \cdot 0 \\
10 \cdot 8 \\
12 \cdot 7\end{array}$ & $\begin{array}{l}2 \cdot 25 \\
2 \cdot 0 \\
2 \cdot 6 \\
1 \cdot 5 \\
2 \cdot 4\end{array}$ & $\begin{array}{r}5 \cdot 1 \\
7 \cdot 1 \\
8 \cdot 8 \\
10 \cdot 8 \\
12 \cdot 3\end{array}$ & $\begin{array}{l}1 \cdot 2 \\
1 \cdot 2 \\
1 \cdot 2 \\
1 \cdot 1 \\
1 \cdot 1\end{array}$ & $\begin{array}{r}5 \cdot 3 \\
7 \cdot 2 \\
9 \cdot 4 \\
10 \cdot 8 \\
12 \cdot 5\end{array}$ \\
\hline
\end{tabular}

Experiments with $2 \mathrm{ml}$. of the sample.

two points became clear: (1) The "loss" of $\mathrm{Ca}++$ after oxalate precipitation does not follow any linear relationship (Fig. 2) but is a curve. As the $\mathrm{Ca}++$ content in the decanted water of samples containing pure $\mathrm{Ca}++$ (in samples to which $\mathrm{Na}+$ was added this experiment cannot be made because of the high $\mathrm{Na}+$ content) was zero, the apparent loss of $\mathrm{Ca}++$ can only be due to interference. (2) $\mathrm{Na}^{+}$in a concentration similar to that of human serum does not produce any additional interference when $\mathrm{Ca}^{+}+$samples are simply precipitated without any washing.

\section{Oxalic Acid Interference}

When $\mathrm{HCl}$ is added to redissolve the precipitate, $\mathrm{CaCl}_{2}$ is formed and oxalic acid is liberated. Moreover, some ammonium oxalate is still present as impurity, which is now converted to oxalic acid. As this substance remains in the solution analysed by flame photometry, we thought that oxalic acid was responsible for the interference. To prove this a simple experiment was done: 50 p.p.m. of oxalic acid was added to each standard and measured by flame photometry, these samples having been checked by oxalic acidfree standards. Results are expressed in Fig. 3 and confirmed our suspicion. The similarity of this curve with that shown in Fig. 2 is obvious. That oxalic acid produced a depressant effect on the $\mathrm{Ca}++$ flame has not hitherto been reported, in spite of others (Application Data, DU-9-B ; Schlütz, 1953) having tried to estimate $\mathrm{Ca}++$ by flame photometry after similar precipitation. This effect was quite unexpected but not surprising, since Bills, McDonald, Niedermeier, and Schwartz (1949) have described a similar action of other organic compounds on $\mathrm{Na}+$ estimations. Oxalic acid can be destroyed by several oxidizing agents, but either some of these contain $\mathbf{K}^{+}$as a cation (it is obviously ridiculous to mix the precipitate with $\mathrm{Na}+$ or $\mathbf{K}^{+}$, after it has been precipitated specifically to remove these cations) or else the added substance itself might produce a new interference effect. On the other hand, there is a very simple procedure to destroy the calcium oxalate molecule, i.e., to heat it at any temperature between $300^{\circ}$ and $400^{\circ} \mathrm{C}$. At this temperature it is converted to $\mathrm{CaCO}_{3}$. This step has another advantage: the unknown sample is prepared iv in the same way as the standards, i.e., $\mathrm{HCl}$ is added to $\mathrm{CaCO}_{3}$ to dissolve it.

\section{Results of Precipitating Samples and Destroying Oxalic Acid}

Samples containing $2.5 \mathrm{mg}$., $5 \mathrm{mg}$., $7.5 \mathrm{mg}$., and 10 mg. $/ 100 \mathrm{ml}$. of pure $\mathrm{Ca}++$ were chosen to carry out this experiment. Different samples containing the same amount of $\mathrm{Ca}++$ were estimated as above, and others after being left overnight in the furnace at $300^{\circ}-400^{\circ} \mathrm{C}$. All samples were carried out in duplicate. Results are shown in Table II. Complete agreement between expected and found results was obtained in the samples put in the furnace.

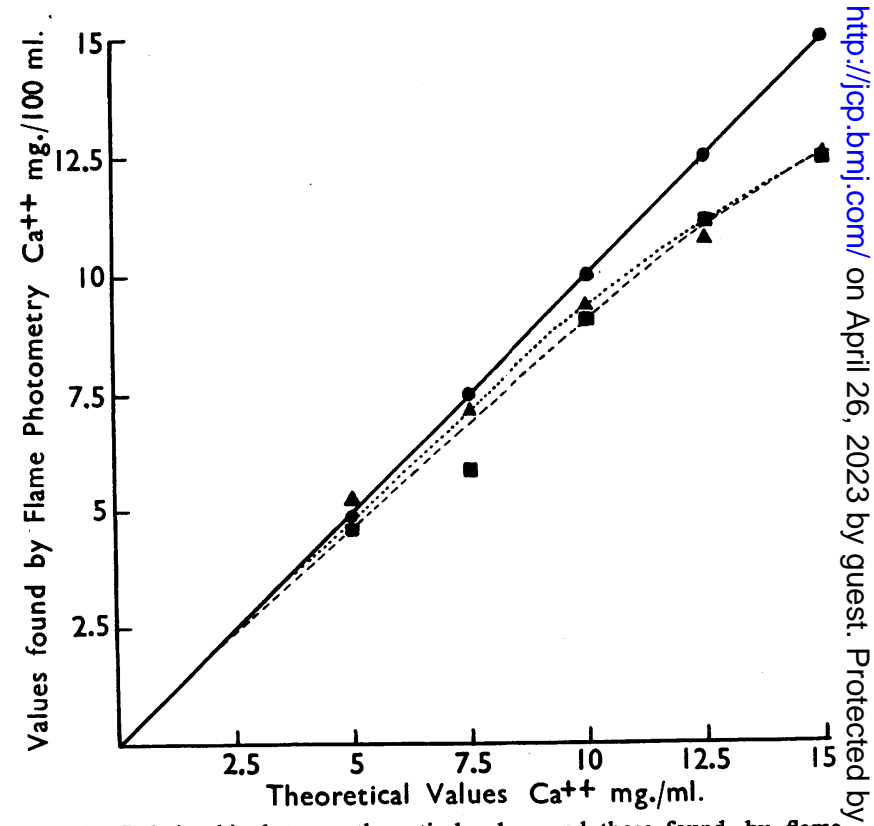
FIG. 2.-Relationship between theoretical values and those found by flame samples. Samples precipitated containing $305 \mathrm{mg} . / 100 \mathrm{ml}$. of $\mathrm{Na}^{+}$. 
TABLE II

RECOVERY OF CALCIUM IN DISTILLED WATER

\begin{tabular}{|c|c|c|c|c|c|c|c|c|}
\hline \multirow{3}{*}{$\begin{array}{l}\text { Theoretical } \\
\text { Values } \\
\text { (mg./100 ml.) }\end{array}$} & \multirow{3}{*}{$\begin{array}{c}\text { Samples } \\
\text { Estimated } \\
\text { Directly } \\
\text { by Flame } \\
\text { Photometer }\end{array}$} & \multicolumn{7}{|c|}{ Samples Precipitated } \\
\hline & & \multicolumn{2}{|c|}{$\mathrm{Ca}^{++}$Content } & \multirow{2}{*}{$\begin{array}{l}\mathrm{Ca}^{++} \\
\text {Mean }\end{array}$} & \multirow{2}{*}{$\begin{array}{c}\mathrm{Na}^{+} \text {as } \\
\text { (Mpurity }\end{array}$} & \multicolumn{3}{|c|}{$\mathrm{Ca}++$ After $400^{\circ} \mathrm{C}$. in Furnace } \\
\hline & & & Duplicate & & & & Duplicate & Mean \\
\hline $\begin{array}{r}2 \cdot 5 \\
5 \cdot 0 \\
7 \cdot 5 \\
10 \cdot 0\end{array}$ & $\begin{array}{r}2 \cdot 6 \\
5 \cdot 0 \\
7 \cdot 5 \\
10 \cdot 0\end{array}$ & $\begin{array}{l}2 \cdot 8 \\
4 \cdot 4 \\
6 \cdot 6 \\
8 \cdot 2\end{array}$ & $\begin{array}{l}2 \cdot 9 \\
4 \cdot 2 \\
6 \cdot 4 \\
8 \cdot 2\end{array}$ & $\begin{array}{l}2 \cdot 85 \\
4 \cdot 3 \\
6 \cdot 5 \\
8 \cdot 2\end{array}$ & $\begin{array}{l}1 \cdot 8 \\
1 \cdot 1 \\
1 \cdot 1 \\
1 \cdot 2\end{array}$ & $\begin{array}{l}2 \cdot 7 \\
5 \cdot 0 \\
7 \cdot 5 \\
9 \cdot 8\end{array}$ & $\begin{array}{l}2 \cdot 7 \\
5 \cdot 0 \\
7 \cdot 4 \\
9 \cdot 8\end{array}$ & $\begin{array}{l}2 \cdot 7 \\
5 \cdot 0 \\
7 \cdot 45 \\
9 \cdot 8\end{array}$ \\
\hline
\end{tabular}

Experiments with $2 \mathrm{ml}$. of sample.

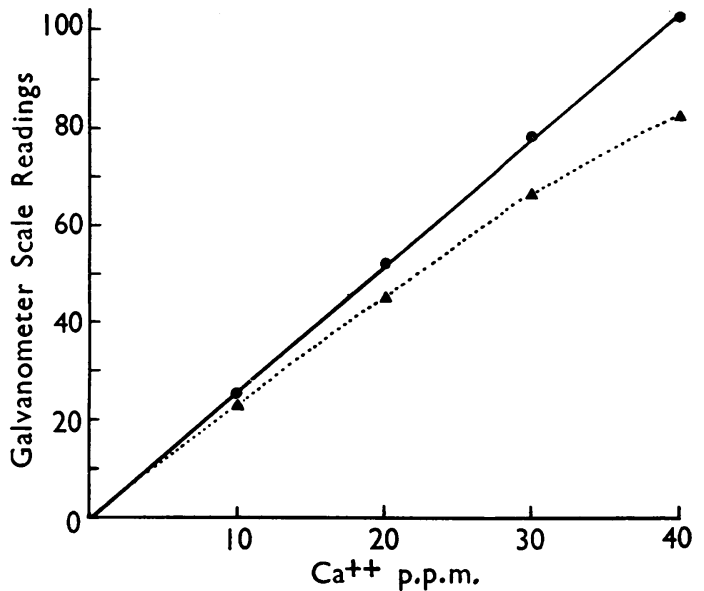

FIG. 3.-Interference effect of oxalic acid on $\mathrm{Ca}^{++}$flame excitation. Samples diluted with distilled water only. Samples diluted with distilled water containing 50 p.p.m. of oxalic acid.

\section{Experiments on Recovery of $\mathbf{C a}^{++}$in Serum}

Since the method was working perfectly, it was decided to apply the technique to human serum. Serum was obtained from the same subject throughout and was diluted $3: 2(\mathrm{v} / \mathrm{v})$ with distilled water. This dilution was used to economize in serum and to bring the $\mathrm{Ca}++$ values to about $9 \mathrm{mg} . / 100 \mathrm{ml}$., when different amounts of $\mathrm{Ca}++$ were added. One $\mathrm{mg}$., $2 \mathrm{mg}$., 3 mg., and $4 \mathrm{mg} . / 100 \mathrm{ml}$. of $\mathrm{Ca}++$ were added to different samples of this serum. All were done in duplicate. In this experiment only $1 \mathrm{ml}$. of the sample was taken in each tube, instead of $2 \mathrm{ml}$. used in the above experiments. The results are shown in Table III. Recovery of $\mathrm{Ca}++$ was complete.
Several estimations in normal sera have since been made, and results ranging from 9.6 to $10.5 \mathrm{mg}$./ $100 \mathrm{ml}$. found. Values found in urine change with the metabolic status of the person as shown by chemical methods. It has also been applied to the estimations of $\mathrm{Ca}^{+}+$in cerebrospinal fluid, tap water, and milk.

\section{Detailed Technique of Calcium Estimation by Flame Photometry}

One ml. of sample is put in a $15 \mathrm{ml}$. conical "pyrex" centrifuge tube, perfectly clean and dry. One $\mathrm{ml}$. of distilled water and $1 \mathrm{ml}$. of saturated (about $4 \mathrm{~g}$. $/ 100 \mathrm{ml}$.) ammonium oxalate are added. They are mixed by rolling the tube between the palms of the hands and are left standing for 30 minutes. Then $4 \mathrm{ml}$. of distilled $\mathrm{H}_{2} \mathrm{O}$ is added to "wash" free of $\mathrm{Na}^{+}$and the sample mixed again. Samples are centrifuged at 2,500 r.p.m. for 10 to 15 minutes. Supernatant fluid is discarded by very careful decantation and tubes are left inverted on a sheet of filter paper for five minutes. Thus the last drops of liquid containing $\mathrm{Na}^{+}$are absorbed. Tubes are placed overnight in a furnace adjusted at any temperature between $300^{\circ}$ and $400^{\circ} \mathrm{C}$. The precipitate is then dissolved in $5 \mathrm{ml} .0 .2 \mathrm{~N}-\mathrm{HCl}(\mathrm{Na}+$-free). Dissolution is favoured by putting the tubes for two minutes in a boiling water-bath. Samples are diluted 1:1 (this is the proper dilution for serum; greater dilutions may be required by urine or other biological samples), transferred to small beakers, and the actual $\mathrm{Ca}++$ content measured by flame photometry, interpolating the reading of the unknown sample between immediately lower and higher standards.

$\mathrm{Ca}++$ solutions containing $10,20,30$, and 40 p.p.m. are used as standards. The method of prepar-

TABLE III

RECOVERY OF CALCIUM IN SERUM

\begin{tabular}{|c|c|c|c|c|c|c|c|c|}
\hline \multirow{2}{*}{ Samples } & & \multirow{2}{*}{$\begin{array}{c}\mathrm{Ca}^{++} \\
\text {Added } \\
\text { (mg. } 100 \mathrm{ml} .)\end{array}$} & \multirow{2}{*}{$\begin{array}{c}\text { Theoretical } \\
\text { Values } \\
\text { (mg. } 100 \mathrm{ml} \text { ) }\end{array}$} & \multicolumn{3}{|c|}{$\mathrm{Ca}^{++}$Content } & \multirow{2}{*}{$\begin{array}{c}\mathrm{Na}+\text { Content } \\
(\text { Mean }) \\
(\mathrm{mg} / 100)\end{array}$} & \multirow{2}{*}{$\mathbf{K}+$ Conten } \\
\hline & & & & & Duplicate & Mean & & \\
\hline \begin{tabular}{cc}
\multicolumn{3}{c}{ Diluted serum } \\
", & " \\
" & "
\end{tabular} & $\begin{array}{l}\cdots \\
\cdots \\
\cdots \\
\cdots\end{array}$ & $\begin{array}{l}-1 \\
2 \\
3 \\
4\end{array}$ & $\begin{array}{r}\overline{8 \cdot 0} \\
9 \cdot 0 \\
10 \cdot 0 \\
11 \cdot 0\end{array}$ & $\begin{array}{r}7 \cdot 0 \\
8 \cdot 0 \\
9 \cdot 0 \\
10 \cdot 0 \\
10 \cdot 9\end{array}$ & $\begin{array}{r}7 \cdot 0 \\
8 \cdot 0 \\
9 \cdot 0 \\
10 \cdot 0 \\
10.9\end{array}$ & $\begin{array}{r}7 \cdot 0 \\
8 \cdot 0 \\
9 \cdot 0 \\
10 \cdot 0 \\
10 \cdot 9\end{array}$ & $\begin{array}{l}4 \cdot 0 \\
4 \cdot 9 \\
4 \cdot 0 \\
3 \cdot 9 \\
4 \cdot 5\end{array}$ & $\begin{array}{l}0 \\
0 \\
0 \\
0 \\
0\end{array}$ \\
\hline
\end{tabular}

Experiments with $1 \mathrm{ml}$. of sample. Initial $\mathrm{Na}^{+}$content of diluted serum, $233.0 \mathrm{ml} . / 100 \mathrm{ml}$. Initial $\mathrm{K}+$ content of diluted serum, $10.15 \mathrm{mg} . / 100 \mathrm{ml}$. 
ation has been described above. As a routine we make up beforehand the dilutions of all the samples to be analysed in one session.

The procedure to make the $\mathrm{Ca}++$ estimations of samples is the following:

Once the air pressure has been adjusted at $10 \mathrm{lb}$./ sq. in. and the gas supply has been regulated according to the empirical procedure described above, the 0 and the 100 are checked in the galvanometer scalereading. Distilled water is sprayed in the flame photometer and the galvanometer is adjusted at 0 . Then the standard solution D (40 p.p.m. of $\mathrm{Ca}++$ ) is sprayed in the flame photometer and the potentiometer is adjusted between divisions 1 and 2 until a whole deflexion (that is, 100 divisions) is recorded in the galvanometer. The other standard solutions $A$, $B$, and $\mathrm{C}(10,20$, and 30 p.p.m. of $\mathrm{Ca}++$ respectively) are now sprayed and the galvanometer deviations are recorded. Thus, when an unknown solution is estimated, it is possible to know between which two standards it lies. The unknown sample is now sprayed and the galvanometer reading recorded. The standard solution which produced deviations immediately lower and higher than this sample are checked again and the result is calculated by interpolation.

An example illustrates this procedure: a serum sample diluted finally at $\mathbf{1}$ in $\mathbf{1 0}$ for flame photometry estimation gives a deviation of 26 in the galvanometer dial. This lies between standards $\mathbf{A}$ and $\mathbf{B}$, which on re-checking now give deviations of 25 and 52 respectively. The unknown sample contains obviously all the $\mathrm{Ca}++$ of standard $\mathrm{A}$ plus an extra amount. This latter amount is calculated by means of the following formula: $\frac{D}{C}=\frac{d}{x}$ where $D=$ difference of galvanometer deviations between the two standard solutions, $\mathrm{C}=$ difference of $\mathrm{Ca}++$ content between these standard solutions, $d=$ difference of galvanometer deviations between the unknown sample and standard solution immediately below it, $\mathrm{x}=\mathrm{Ca}++$ content of difference d. In the present instance, the equation would be

$$
\frac{52-25}{10}=\frac{26-25}{x} \text { and } x=\frac{10}{27}=0.3
$$

Thus, 0.3 is the extra amount which must be added to 10 p.p.m. ( $\mathrm{Ca}++$ content of standard $\mathrm{A})$. Therefore, the $\mathrm{Ca}++$ content of the diluted analysed sample will be $10+0.3=10.3$ p.p.m., and as it is a 1 in 10 dilution the $\mathrm{Ca}++$ value of the serum will be 10.3 $\times 10=103$ p.p.m., or converting p.p.m. to $\mathrm{mg} . / 100 \mathrm{ml}$., it will be $10.3 \mathrm{mg} . / 100 \mathrm{ml}$.

When a great number of estimations have to be carried out, it is convenient to construct a table, from which the calculated values may be obtained directly.

Occasionally when analysing urine, milk, or other biological materials with high $\mathrm{Ca}++$ content, a solution of 1 in 10 contains still too much $\mathrm{Ca}^{++}$ and the galvanometer deviation reaches more than a whole deflexion. In this case it is necessary to dilute again the sample until the figure recorded in the dial is less than 100. This dilution is a factor by which the $\mathrm{Ca}++$ content of the sample sprayed in the flame photometer must be multiplied in order to obtain the real $\mathrm{Ca}++$ content of the original sample.

When calculating the results in the case of $\mathrm{Ca}++\frac{+}{7}$ serum estimations attention must be drawn to the fact that the initial volume of the serum sample was $1 \mathrm{ml} . \frac{\text { 을 }}{\mathrm{F}}$ the volume when redissolved in $\mathrm{HCl}$ was $5 \mathrm{ml}$. This solution was then diluted by a factor of 2 to make it suitable for flame photometer estimation. There w fore, in the case of serum, the value obtained by analysing the diluted sample must be multiplied by 10 .

In Table III values of $\mathrm{Na}^{+}$apply to non-diluted samples, i.e., those solutions analysed by flame photo $\omega$ metry contained 1 in 10 of the values given; therefore all values of $\mathrm{Na}^{+}$are below $0.8 \mathrm{mg} . / 100 \mathrm{ml}$, that is completely cut off by the $\mathrm{Ca}++$ filter.

Although the step of converting oxalate to car -1 bonate by leaving the tubes in the furnace is very simple, it requires a thermostat, which may not be readily available in all laboratories. To avoid this possible hindrance it was decided to make further experiments using a simple sand-bath. Fine san was placed in a tin tray and heated by one or mork Bunsen burners, a thermometer being placed in the sand to record temperatures. It was observed thas once the required temperature (about $360^{\circ}$ C.) was reached, it could be readily controlled within $10^{\circ} \mathrm{C}_{\odot}$ by slightly adjusting the burner(s). When half the length of the tubes containing the calcium oxalat precipitate was buried in the sand and left for $3 \otimes$ minutes at $360^{\circ} \mathrm{C}$. the complete conversion of oxalat to carbonate was achieved and the values of $\mathrm{Ca}+$ recovery were the same as those obtained by putting the samples in the furnace.

Certain precautions, however, must be taken. The precipitate at the bottom of the tube must b. dry before placing it in the sand. (2) When severaf series of estimations have to be carried out time cap be saved by placing the tubes in the sand-bath at $200 \frac{0}{3}$ C. When the temperature reaches $360^{\circ}$, the conver:sion of oxalate is completed in 30 minutes. (3) Care must be taken that the sand-bath is uniformly heated

\section{Conclusion}

This is a combined chemico-physical metho that makes feasible and easy the estimation of the true amounts of $\mathrm{Ca}^{++}$in biological samples eveñ when mixed with $\mathrm{Na}^{+}, \mathrm{K}^{+}$, and other biologicat substances, such as proteins, etc. The advantages over usual chemical methods can be summarized as follows:

It avoids the repeated washings and the res centrifugations.

It suppresses the tedious step of titration, substis tuting an estimation on the flame photometer tha takes 10 seconds. For this reason it is an exf tremely useful method when a large number of
$\mathrm{Ca}^{+}+$estimations must be made.

Complete accuracy is reflected in the objectio data given. The slightly high results that are often 
obtained by manganometry, due to the presence of reducing substances, are obviated by this method.

Flame photometry for $\mathrm{Na}^{+}$and $\mathrm{K}^{+}$estimations is becoming a common method in this country and the same apparatus can be used for $\mathrm{Ca}^{++}$estimations with the simple addition of the filter for $\mathrm{Ca}^{++}$.

\section{Summary}

A method is described in detail for estimating $\mathrm{Ca}^{++}$when mixed with other cations in biological materials, using a commonly available type of flame photometer, burning simple coal-gas and equipped with an interference filter.

An absolutely linear relationship between galvanometer deviations and $\mathrm{Ca}^{++}$concentrations ranging from 0 to 40 p.p.m. is shown.

$\mathrm{Na}^{+}$and $\mathrm{K}^{+}$concentrations which can be admitted as "impurities" without affecting $\mathrm{Ca}++$ estimation are discussed.

An interference effect of oxalic acid on $\mathrm{Ca}++$ flame excitation is described for the first time.
This is overcome by heating the samples at $300^{\circ}-$ $400^{\circ} \mathrm{C}$., which destroys oxalic anion.

The complete recovery of $\mathrm{Ca}^{++}$in distilled water and in human serum is shown in tables.

Advantages of the present method over routine chemical methods are that it avoids the repeated washings and subsequent recentrifugations and the tedious titration, and gives greater accuracy.

I am indebted to the British Council for the tenure of a grant during the performance of this work; to Professor E. J. King for suggesting this work; to Professor J. McMichael, in whose Department this research was carried out; to Dr. I. D. P. Wootton for his helpful advice; to Dr. C. L. Cope and Dr. C. E. Dalgliesh for their criticism and help when preparing the manuscript.

\section{References}

Application Data for Beckman Instruments, DU-9-B.

Barnes, R. B., Richardson, D., Berry, J. W., and Hood, R. L. (1945). Industr. Engng Chem., Anal. Ed., 17, 605.

Belke, J., and Dierkesmann, A. (1948). Arch. exp. Path. Pharmak., $205,629$.

Bills, C. E., McDonald, F. G., Niedermeier, W., and Schwartz, M. C. (1949). Anal. Chem., 21, 1076.

Bohnstedt, R. M., Herrmann, R., Baumann, R., and Füller, H. (1953). Arztl. Forsch., 7, 82.

Herrmann, R. (1952). Z., ges. exp. Med., 118, 187.

Schlütz, G. O. (1953). Schweiz. med. Wschr., 83, 383. 